\title{
The effect of tungstate ingestion on xanthine oxidase in milk and liver
}

\author{
By E. C. OWEN AND R. PROUDFOOT* \\ Biochemistry Department, Hannah Dairy Research Institute, Ayr
}

(Received 14 fuly 1967-Accepted 29 fanuary 1968)

\begin{abstract}
I. The ingestion of doses of up to $6 \mathrm{~g}$ sodium tungstate $(56 \mathrm{mg} \mathrm{W} / \mathrm{kg}$ body-weight) by goats was found to diminish the amount of xanthine oxidase secreted in their milk so that, in some samples, the enzyme became undetectable. This effect occurred whether the goats were eating a semi-synthetic or a conventional diet.

2. Tungstate ingestion by goats did not affect the concentration of riboflavine in their milk.

3. The ingestion of sodium tungstate by young goats for 3-5 months diminished the amount of xanthine oxidase in their livers.

4. When given in early lactation to two cows, doses of sodium tungstate (up to $20 \mathrm{~g}$ ) diminished the titre of xanthine oxidase in their milk with no concomitant effect on the yields.

5. Much later in lactation the milk phosphatase of these two cows was poorly correlated with milk xanthine oxidase. Reasons for this are discussed.

6. Under anaerobic conditions, with xanthine as substrate and triphenyl-tetrazolium chloride as hydrogen acceptor, neither molybdate nor tungstate affected the xanthine oxidase activity of cow's or goat's milk in vitro. Molybdate in vitro did not enhance the very low titre of human milk.
\end{abstract}

Xanthine oxidase (xanthine:oxygen oxidoreductase, EC $\mathbf{1}$.2.3.2.) (XO) is an enzyme which is widely distributed in living organisms occurring as it does in both bacteria and animals. Its structure is fairly well known since Bergel and his colleagues isolated it crystalline from milk (Avis, Bergel, Bray \& Shooter, 1956; Bray, Chisholm, Hart, Meriwether \& Watts, 1966). It consists of protein combined with flavine adenine dinucleotide, iron and molybdenum. Protein, certain individual amino acids, riboflavine and molybdenum in the diet of the rat and injected salts of iron have all been shown to influence the amount of the enzyme present in the liver and the intestinal wall. Richert \& Westerfeld (1953) and De Renzo, Kaleita, Heytler, Oleson, Hutchings \& Williams (1953) demonstrated that molybdate was what Richert \& Westerfeld (I953) had called the 'xanthine oxidase factor' in the rat's diet.

Crossland, Owen \& Proudfoot (1958) showed that a diet deficient in riboflavine, lysine and tryptophan did not affect the appearance of $\mathrm{XO}$ in the milk of the goat, and Modi, Owen \& Proudfoot (1959) found the enzyme in the milk of the goat, cow, sheep and rabbit, but not in the milk of the mare or sow. It was formerly believed that XO does not occur in human milk, but by using Bradley \& Gunther's (1960) more sensitive test, Owen, Hart \& Hytten (1962) were able to confirm Bradley \& Gunther's (I960) report that XO does occur in human milk in small amounts.

The distribution of $\mathrm{XO}$ from species to species of animal or from one insect to another or from one type of bacterium to another is sporadic and the distribution between tissues in an animal varies with species. Thus the rat has the enzyme in both the liver and

\footnotetext{
* Present address: Physiological Laboratory, Cambridge.
} 
small intestinal wall, whereas the pigeon has this enzyme in the kidney but not in the liver. Roussos ( 1963 ) and Roussos \& Morrow ( 1966 ) have reported that in the xanthine oxidase prepared from bovine small intestine, copper is present with iron and flavine adenine dinucleotide, but that molybdenum is absent.

The existence of an XO-free mutant of Drosophila melanogaster shows that genetic influences can control the production of this enzyme (Keller \& Glassman, I964). XO occurs in the central nervous system of mammals for Bauer \& Bradley ( $195^{6}$ ) compared the changes of its concentration in the brains of mice infected with various neurotropic viruses.

De Renzo (1954) and Higgins, Richert \& Westerfeld (I956) showed that the powers of the rat to form XO and the chick to form the very similar enzyme xanthine dehydrogenase are specifically inhibited by the ingestion of tungstate. The study of the effect of orally administered tungstate on XO in the milk and liver of the goat and in the milk of the cow which is the subject of the present paper, forms part of our current researches on riboflavine metabolism (West, Owen \& Taylor, 1967; Owen \& West, 1968).

\section{EXPERIMENTAL}

There were six experiments; Expts I and 2 were with goats in milk, Expt 3 was with kids, Expts 4 and 5 were with cows, and Expt 6 was a study of the effect on the XO activity of milk of adding molybdate or tungstate in vitro.

Animals. The goats in Expts $\mathrm{I}-3$ were from the British Saanen herd which is maintained by the Biochemistry Department of the Institute. Riboflavine was measured in the milk of the adult animals.

In Expt 4 two Ayrshire cows were studied throughout a long period of lactation. At the beginning of lactation the effect of tungstate was studied. Near the end of lactation phosphatase titres, which are well known to be large at that time, were compared (Expt 5) with XO titres.

Estimation of xanthine oxidase. The anaerobic procedure of Zittle, Dellamonica, Custer \& Rudd (1956) was employed. Xanthine was omitted for the blank determinations. These blanks were easily measurable in cow's milk but in goat's milk they were often negligible. Blanks on boiled milk showed some colour since this enzyme is not completely destroyed by heating. Large blanks were found in liver due to the wellknown non-specific reduction of the triphenyl-tetrazolium chloride (TTC), but the enzyme activity could still be calculated from the increased production of formazan from the TTC in the presence of xanthine. By dissolving weighed amounts of triphenyl formazan, prepared from TTC, in toluene the $E_{1}^{1 \%} 4_{5} \mathrm{~nm}$ was found to be 5 II $(510-512)$ which is comparable with the $E$ value calculable from the results of Zittle et al. (1956). Estimation of the chloride in the TTC by titration with silver nitrate indicated a purity of $99 \cdot 7\left(9^{8} \cdot 9^{-100 \cdot 2}\right)$. Experiments showed that on the same milk samples the conditions of Zittle $e t$ al. gave the same results when Thunberg tubes replaced the open tubes normally used.

Using phosphate buffer we found that the optimal rate of production of the formazan is at $\mathrm{pH} 7 \cdot 4$. Aerobically the optimum $\mathrm{pH}$ of milk XO is $9 \cdot \circ$ (Hart, Owen \& Proud- 
foot, 1967). This change of $\mathrm{pH}$ optimum with change from aerobic to anaerobic conditions has since been noted by Muraoka, Enomoto, Sugiyama \& Yamasaki (1967).

The milk samples were stored in a refrigerator for $\mathrm{I}$ or 2 days before analysis; they were then thawed and passed through a hand-operated homogenizer to improve the sampling of duplicates before diluting $\mathrm{I}: 5$ for testing.

Manometric methods of the Warburg type are insufficiently sensitive for the estimation of $\mathrm{XO}$ when very small amounts of the enzyme are expected, and the sensitivity of the TTC method is readily enhanced by prolonging the incubation from to min to 30 or $60 \mathrm{~min}$ as recommended by Bradley \& Gunther (1960).

Estimation of riboflavine in milk. The method of Crossland et al. (1958) was used.

Estimation of phosphatase in milk. Phosphatase was estimated by the method of Neave (1939) simplified by adding diatomaceous earth (Hyflosupercel; from JohnsManville and Co. Ltd) and centrifuging to eliminate the filtration on paper that Neave advised. By this means one of the pipettings in the original method was also eliminated. The colour produced was read in an EEL Colorimeter (Evans Electroselenium Ltd) using the red filter.

Administration of drugs. Sodium molybdate, sodium tungstate and riboflavine (British Drug Houses, Ltd) were each given to the animals by dosing gun. Small doses as in Expt I were given in gelatine capsules and larger ones for goats or cows were wrapped in paper.

Diet and management of the animals. During experiments all animals were kept indoors in stalls.

Expt I. The goats of Expt I received a diet similar to that of Crossland et al. (1958) but with the salt mixture replaced by that of Miller, Price \& Engel (1956) in which sulphate is avoided by using chloride salts. Sodium molybdate was added to bring the Mo: Cu ratio to $\mathrm{r}: 20$, the ratio found by Mitchell (1948) in pastures on which healthy sheep had been reared. These four goats were dosed with riboflavine ( $0.1 \mathrm{~g})$, sodium molybdate $(0.4 \mathrm{~g})$, sodium tungstate ( $\mathrm{I} \mathrm{g}$ ) or a mixture of equal parts of sodium and potassium sulphates ( $2 \mathrm{~g}$ ). Mixtures of riboflavine with molybdate or tungstate were also given. The treatments were given in random order except that the two goats that received molybdate did not receive tungstate and vice versa. The day before and the day after each treatment the milk of each goat was analysed for riboflavine and XO.

Expt 2. In this experiment four milking goats, maintained on a conventional diet of oats, beans, dried grass and hay were given single doses of sodium tungstate.

Expt 3. Six male kids were fed for 3-5 months on the diet shown in Table I, three receiving the basal diet and three others the diet supplemented with $45 \mathrm{mg}$ sodium tungstate $\left(\mathrm{Na}_{2} \mathrm{WO}_{4} \cdot 2 \mathrm{H}_{2} \mathrm{O}\right.$; British Drug Houses Ltd, Analar Grade)/kg concentrate mixture. This produced, as shown in Table $\mathrm{I}$, a dietary ratio of $\mathrm{W}: \mathrm{Mo}=20 \cdot 6$ which is far below the ratio at which tungstate becomes toxic according to Higgins et al. (1956), who showed that tungstate in the diet can deplete rats of XO and chickens of the analogous enzyme, xanthine dehydrogenase. At slaughter XO was determined in an aqueous homogenate of liver.

Expt 4. Two Ayrshire cows were studied from the $4^{\text {th }}$ to the $14^{\text {th }}$ week of lactation, the XO in their milk being measured daily (see Table 3 ). As concentrates, they were 
given a mixture (in parts by weight) of bruised oats 6 , wheat bran $\mathrm{I}$, field beans (Vicia faba) 2 and decorticated, fat-free, groundnut meal (Arachis hypogaea) I. This mixture was fed at a rate of $0.4 \mathrm{~kg} / \mathrm{kg}$ of milk, the ration each week being calculated from the yield of the preceding fortnight. For maintenance, the cows received $0.9 \mathrm{~kg}$ dried beet pulp and oat straw to appetite; the straw was restricted if they failed to eat their concentrates on any particular day. Each cow was dosed with sodium tungstate twice. Cow no. $\mathrm{I}$ received $10 \mathrm{~g}$ on the first and $20 \mathrm{~g}$ on the second occasion, and cow no. 2 received $20 \mathrm{~g}$ on the first and $\mathrm{ro} g$ on the second occasion. During the 5 months which elapsed after the end of Expt 4 these two cows were frequently dosed with sodium molybdate in endeavours to increase the titre of $\mathrm{XO}$ in their milk, but all these attempts were unsuccessful even when extra iron (as ferric phosphate), extra protein (as a mixture of blood meal and potato starch), or extra sulphate (as an equimolar mixture of the sodium and potassium salts) were given with the molybdate. These latter results therefore will not be further considered.

Expt 5. The cows of Expt 4 were kept milking beyond the time when they would normally have been dried off and during their Ioth and I ith months of lactation a statistical comparison was made between the $\mathrm{XO}$ and the phosphatase titres of their milk.

Expt 6. This concerned the effect on $\mathrm{XO}$ of adding tungstate or molybdate to milk in vitro.

Table r. Expt 3. Composition of rations for kids

\begin{tabular}{|c|c|c|}
\hline Constituent & $\begin{array}{l}\text { Parts by } \\
\text { weight }\end{array}$ & $\begin{array}{c}\text { Mo } \\
(\mathrm{ppm}) *\end{array}$ \\
\hline \multicolumn{3}{|c|}{ Concentrates $(0.67 \mathrm{~kg} /$ day kid) } \\
\hline Bruised oats & 6 & 0.23 \\
\hline Bean meal (Vicia faba) & 3 & 0.91 \\
\hline Flaked maize & I & 0.21 \\
\hline $\begin{array}{l}\text { Decorticated groundnut } \\
\text { (Arachis hypogaea) } \\
\text { Roughage }\end{array}$ & $\mathbf{I}$ & $4 \cdot 5$ \\
\hline Cocksfoot hay & (to appetite) & 0.35 \\
\hline Average content for the & s a wholet & 0.57 \\
\hline
\end{tabular}

* Analysed by L. I. Hart using toluene-3,4-dithiol (Hart, 1964).

$\uparrow$ Assuming each animal consumed equal amounts of concentrates and roughage $(0.67 \mathrm{~kg}$ of each/day) the experimental diet, which had $45 \mathrm{mg}$ added $W / \mathrm{kg}$ concentrates, would supply $22 \cdot 5 \mathrm{mg} W / \mathrm{kg}$ food or a $W:$ Mo atom ratio of $20 \cdot 6$.

\section{RESULTS}

Expt I. Effect of tungstate on lactating goats. No effects on the activity of XO in milk attributable to riboflavine, molybdate or sulphate were found, but tungstate produced a strong and lasting depressive effect on milk XO. Thus in one of the two goats which received tungstate, $\mathrm{XO}$ in the milk fell from 0.032 to 0.004 unit. It then recovered to 0.024 unit on the following day. When a second dose of tungstate was given the milk showed an XO titre of 0.003 . The second tungstate-treated goat had an XO titre which fell from 0.025 to 0.009 when tungstate was first given and from 0.016 to zero when the second dose of tungstate was given.

Expt 2. Effect of tungstate on lactating goats. As Fig. I shows, a single dose of sodium 
tungstate caused a marked drop in the titre of XO in the milk of goats nos. I and 2, but about a week later the titre of XO began to rise and continued to rise slowly in goat no. I. When goat no. 2 received a second dose of tungstate, the $\mathrm{XO}$ in its milk was again diminished for about a week.

Riboflavine in the milk of goat no. I of Fig. I, ranged from 2.02 to $3.54 \mathrm{ppm}$ of milk, the average of thirteen consecutive analyses being $3.12 \mathrm{ppm}$. After the dose of tungstate, the range of riboflavine in the milk of this goat was 1.74 to $3.30 \mathrm{ppm}$ with an average of $2.50 \mathrm{ppm}$ milk. At the outset, the mean concentration of riboflavine in the milk of goat no. 2 was $3.34 \mathrm{ppm}$ (range $2 \cdot 80-3.73$ ) and after the tungstate, the range was $\mathrm{I} \cdot 80-4 \cdot 5^{8} \mathrm{ppm}$ milk, the mean of thirty-five consecutive analyses being $2 \cdot 95 \mathrm{ppm}$.

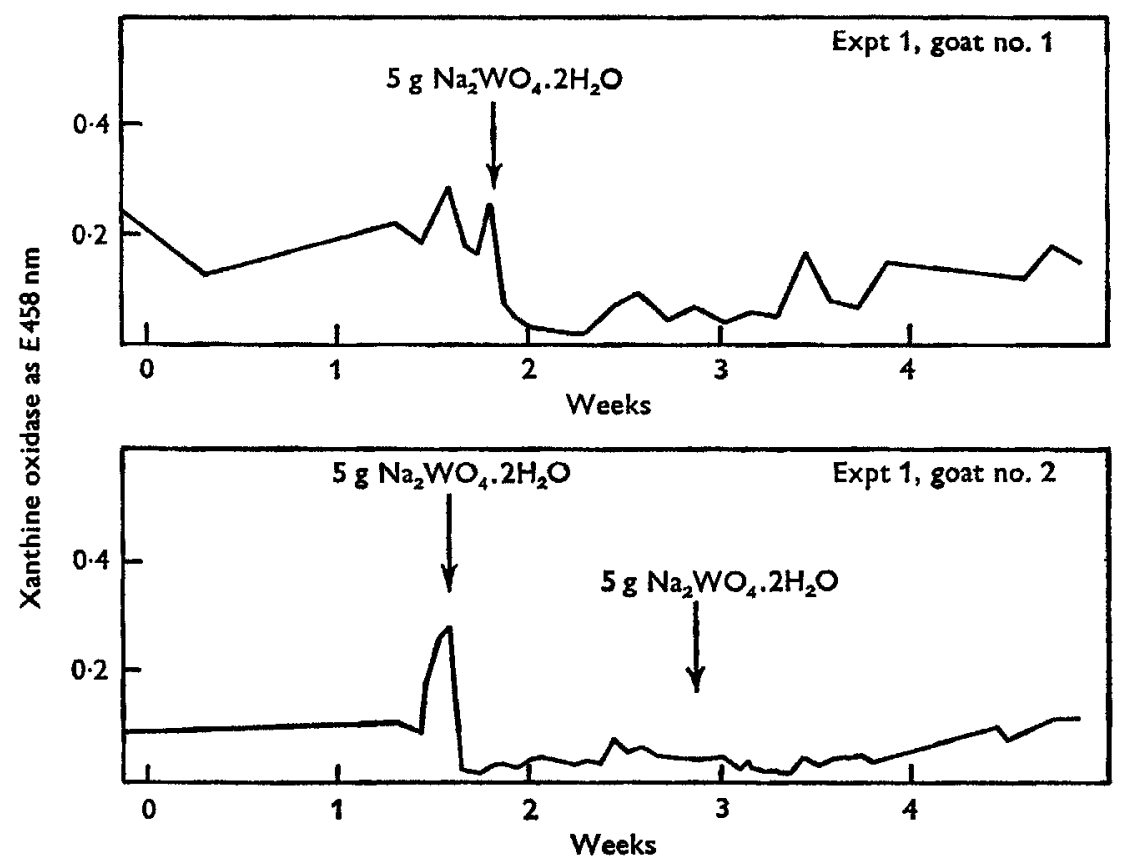

Fig. I. Effect of tungstate on the activity of xanthine oxidase in the milk of goats. At the times indicated by the arrows, the goats ingested $5 \mathrm{~g}$ sodium tungstate $\left(\mathrm{Na}_{2} \mathrm{WO}_{4} \cdot 2 \mathrm{H}_{2} \mathrm{O}\right)$. Ordinates are $E \mathbf{4 5 8} \mathbf{n m}$ of formazan in toluene. Each point on the graph is a mean of duplicates.

These riboflavine values illustrate the fact already observed in cows by Modi, Owen $\&$ Darroch (1959), that as lactation advances the riboflavine content of the milk tends to decline gradually. Comparison of the results with those of Crossland et al. (1958) showed that the tungstate had not affected the concentration of riboflavine in the milk. The riboflavine which is part of the $\mathrm{XO}$ molecule is only a small proportion of the total riboflavine in goat's milk so that tungstate, in spite of its effect in diminishing XO, evidently did not affect significantly the concentration of free riboflavine in the goat's milk. Two other goats which were studied for 3 weeks showed average daily XO titres of 0.037 and 0.068 in their milk during the Ist week. At the beginning of the 2 nd week they each ingested $5 \mathrm{~g}$ sodium tungstate and during this $2 \mathrm{nd}$ week the average daily titres of $\mathrm{XO}$ in their milk were 0.010 and 0.013 respectively. On 5 days of this 
week in each of the goats XO could not be detected. During the $3^{\text {rd }}$ week the XO in the milk averaged 0.018 and 0.043 respectively. There were no occasions during the Ist or $3^{\text {rd }}$ week when the $\mathrm{XO}$ was undetectable.

Expt 3. Effect of sodium tungstate in the diet, on the liver of growing kids. As can be seen from Table 2, the amounts of XO in the livers of the kids after 3-5 months on the diet with tungstate were much smaller than in any of the controls, so that in the kid tungstate had an effect similar to that in the rat and chicken. In the rat, liver XO is an index of the biological value of the dietary protein (Munro, 1964). In the ruminant this biological value is affected by the rumen bacterial flora (Owen, 1967) which may account for the greater XO values for the control animals nos. 2 and 3 which were 5 months on the diet compared with control animal no. I which was given it for only 3 months.

Table 2. Expt 3. Xanthine oxidase in the livers of male kids

\begin{tabular}{|c|c|c|c|c|c|c|}
\hline \multirow[b]{2}{*}{ Kid no. } & \multirow[b]{2}{*}{ Diet } & \multirow[b]{2}{*}{$\begin{array}{c}\text { Time on } \\
\text { diet } \\
\text { (months) }\end{array}$} & \multirow[b]{2}{*}{$\begin{array}{c}\text { Initial } \\
\text { body-weight } \\
\text { (lb) }\end{array}$} & \multicolumn{3}{|c|}{$\begin{array}{l}\text { Formazan*/g liver per } \\
20 \mathrm{ml} \text { homogenate }\end{array}$} \\
\hline & & & & $\begin{array}{l}\text { No xanthine } \\
\text { added } \uparrow(a)\end{array}$ & $\begin{array}{l}\text { Xanthine } \\
\text { added }(b)\end{array}$ & $\mathrm{XO}=(\mathrm{b}-\mathrm{a})$ \\
\hline $\left.\begin{array}{l}1 \\
2 \\
3\end{array}\right\}$ & Control & $\left\{\begin{array}{l}3 \\
5 \\
5\end{array}\right.$ & $\begin{array}{l}40 \\
30 \\
26\end{array}$ & $\begin{array}{l}37 \\
76 \\
17\end{array}$ & $\begin{array}{l}196 \\
570 \\
385\end{array}$ & $\begin{array}{l}159 \\
494 \\
368\end{array}$ \\
\hline $\left.\begin{array}{l}4 \\
5 \\
6\end{array}\right\}$ & $\begin{array}{l}\text { Containing } \\
\text { tungstate }\end{array}$ & $\left\{\begin{array}{l}5 \\
5 \\
3\end{array}\right.$ & $\begin{array}{l}50 \\
38 \\
26\end{array}$ & $\begin{array}{r}168 \\
31 \\
125\end{array}$ & $\begin{array}{l}248 \\
128 \\
171\end{array}$ & $\begin{array}{l}80 \\
97 \\
46\end{array}$ \\
\hline
\end{tabular}

* Each figure is an extinction in the Unicam $\mathrm{SP}_{500}$ at $485 \mathrm{~nm}$ in a $\mathrm{x} \mathrm{cm}$ cell of the formazan produced by $1 \mathrm{ml}$ homogenate solution extracted into $4 \mathrm{ml}$ toluene. To obtain the values in the table each result has been multiplied by 1000 .

$\dagger$ This figure represents the formazan produced by non-specific reduction of TTC by tissue constituents.

Expt 4. Effect of tungstate on XO in cow's milk. Table 3 shows that the effect of the tungstate on the milk was to produce a sudden drop in its XO titre followed by a rapid regain of XO titre. The tungstate thus rapidly produced the minimal values of XO shown on the $3^{\text {rd, }} 4^{\text {th }}$ or $5^{\text {th }}$ days after treatment in Table 3 , but there were no samples of milk in which XO could not be easily measured.

In marked contrast to its effects on goats in Expts 1 and 2 the effect of tungstate on the XO in the milk of the cows was rapid but transient.

The milk yield of cows nos. I and 2 averaged 10.9 and $12.5 \mathrm{~kg} /$ day respectively over the first fortnight of the experiment and declined at a regular rate which was unaffected by the tungstate treatments. The average yields over the whole period shown in Table 3 were $10.7 \mathrm{~kg} /$ day for cow no. I and $11.5 \mathrm{~kg} /$ day for cow no. 2. It can thus be concluded that the diminished XO titres in the milk after tungstate were indicative of diminutions in the output of XO by the mammary gland.

Expt 4 started on the same day for each cow, but treatments were designedly not simultaneous, so that during treatment each cow acted as a control for the other. For the 19 days when tungstate was affecting one or other of the two cows the XO titres averaged 0.283 and the corresponding control values 0.549 . By the $t$ test (Fisher \& Yates, 1938) the difference between these means was significant at $P<0.00$ r. 
At the end of Ey.pt 4 in Table 3 the milk XO declined further and remained low in late lactation. Nevertheless, we have never encountered a zero value for XO in cow's milk. Possibly this is because a dose of 5 or $6 \mathrm{~g}$ sodium tungstate to a goat weighing $50-60 \mathrm{~kg}(56 \mathrm{mg} \mathrm{W} / \mathrm{kg})$, on a body-weight basis, is much more than a dose of $20 \mathrm{~g}$ to a cow weighing about $450 \mathrm{~kg}(25 \mathrm{mg} \mathrm{W} / \mathrm{kg})$.

Table 3. Effects of ingestion of sodium tungstate on the activity of xanthine oxidase in the milk of two cows

\begin{tabular}{|c|c|c|c|c|c|c|c|c|c|}
\hline \multirow[b]{3}{*}{$\begin{array}{l}\text { Cow } \\
\text { no. }\end{array}$} & \multirow[b]{3}{*}{ Dose } & \multirow[b]{3}{*}{$\begin{array}{l}\text { Tungstate } \\
\text { treatment }\end{array}$} & \multicolumn{7}{|c|}{ Xanthine oxidase activity (units $\times 1000$ ) } \\
\hline & & & \multirow{2}{*}{$\begin{array}{l}\text { Preliminary } \\
\text { period } \\
\text { mean } \pm \text { SD) }\end{array}$} & \multicolumn{6}{|c|}{ Days after first dose } \\
\hline & & & & I & 2 & 3 & 4 & 5 & $\begin{array}{c}6-10 \\
(\text { mean } \pm S D)\end{array}$ \\
\hline $\mathbf{I}$ & $\mathbf{I}$ & Iog on Ist day & $\begin{array}{l}504 \pm 104 \\
\text { (I6 days) }\end{array}$ & 655 & 460 & 170 & 310 & 360 & $544 \pm 149$ \\
\hline & $2 *$ & $\begin{array}{l}\text { Io } g \text { on ist day } \\
\text { Io } g \text { on } 2 \text { nd day }\end{array}$ & $\begin{array}{l}629 \pm 54 \\
\text { (10 days) }\end{array}$ & 670 & 500 & 500 & 240 & roo & $3^{8} 7 \pm 192$ \\
\hline 2 & $\mathbf{I}$ & $20 \mathrm{~g}$ on Ist day & $\begin{array}{l}588 \pm 100 \\
\text { (16 days) }\end{array}$ & 680 & 660 & 575 & 210 & 220 & $472 \pm 13^{6}$ \\
\hline & $2 *$ & ro g on ist day & $\begin{array}{l}65^{8} \pm 48 \\
\text { (10 days) }\end{array}$ & 640 & 430 & 575 & $33^{\circ}$ & 125 & $288 \pm r_{32}$ \\
\hline
\end{tabular}

Expt 5. Comparison of xanthine oxidase and phosphatase in cow's milk. When the two cows of Expt 4 were in advanced lactation XO was very low and phosphatase abundant. Over a period of 4 weeks the concentrations of these two enzymes were compared. Phosphatase titres were $85.4 \pm 18 \cdot 2(\mathrm{SD})$ and $85^{\circ} \mathrm{I} \pm 6 \cdot 2(\mathrm{SD})$ for cows $\mathrm{I}$ and 2 respectively. XO titres were $0.044 \pm 0.022(\mathrm{SD})$ and $0.083 \pm 0.053(\mathrm{SD})$. During these 4 weeks the cows were dosed with tungstate and, as can be seen from ratios of the standard deviations to their means, there was little if any effect on the titres of phosphatase, those of XO being subject to much more variation. Coefficients of correlation between phosphatase and xanthine oxidase were positive but were not statistically significant, $r$ being +0.37 for eighteen paired observations for cow no. I and +0.20 for twenty paired observations for cow no. 2.

Expt 6. Effect of tungstate and molybdate on milk in vitro. Cow's milk and goat's milk were tested both before and after adding molybdate or tungstate as standard solutions of their sodium salts. Cow's milk with an XO titre of 0.808 before adding $0.2 \mathrm{mg} \mathrm{Mo} /$ $\mathrm{ml}$ milk had a titre of 0.828 afterwards. One of 0.616 showed 0.539 after the addition of $0.5 \mathrm{mg} \mathrm{Mo} / \mathrm{ml}$ milk. A goat's milk with a titre of 0.017 showed 0.014 after adding $0.2 \mathrm{mg} \mathrm{Mo} / \mathrm{ml}$. Three samples of cow's milk showed $0.649,0.839$ and 0.859 before and $0.666,0.833$ and 0.955 respectively after the addition of $0.25 \mathrm{mg} \mathrm{W} / \mathrm{ml}$ and a sample of goat's milk of XO titre 0.083 was unchanged by the addition of $\mathrm{I} \mathrm{mg} \mathrm{W} / \mathrm{ml}$ milk. Cow's milk contains 20-30 mg Mo/l. and goat's milk about half this concentration (Hart et al. 1967). The amounts added to the milk samples in this experiment were therefore considerably in excess of the amounts of Mo naturally present but none of the changes in $\mathrm{XO}$ in milk was in excess of natural variations. The changes 
produced in Expts I, 2 and 4 in XO could not therefore have been due to any direct effect of the tungstate on the milk of the cows or the goats. Human milk was found to have the same low titre of $\mathrm{XO}$ both before and after addition of Mo in vitro.

\section{DISCUSSION}

\section{Tungstate interference with the metabolism of molybdenum}

The foregoing experiments demonstrate that tungstate inhibits the production of xanthine oxidase in the milk of the cow and the goat and that it inhibits the storage of the enzyme in the liver of the young goat. In the latter respect its effects are analogous to those found by Higgins et al. (1956) on xanthine oxidase in the liver and intestine of the rat and on the xanthine dehydrogenase (XD) in the liver of the chicken. These effects in the rat and the chicken are attributable to an antagonism in the body between tungstate and molybdate whose chemical reactions present many similarities. Even in bacteria this antagonism has been recorded. Pinsent (1954), for example, found that Escherichia coli requires molybdate to enable it to produce formic dehydrogenase and that tungstate is competitively antagonistic to molybdate, and Affonso \& Mitidieri (1965) found competitive inhibition of molybdate by tungstate in the production of XD by Pseudomonas aeruginosa. Higgins et al. (1956) found that tungstate causes the rat to excrete molybdate in its urine and so presumably limits storage in the body to concentrations insufficient for optimal elaboration of the enzyme XO. Sulphate, which Dick (1956) found to be capable of depleting the stores of Mo in sheep, was found by Higgins et al. (1956) to have no comparable action on XO, but Miller et al. (1956) found that sulphate could prevent the inhibition of growth and the storage of excess $\mathrm{Mo}$ and $\mathrm{Cu}$ in the liver which result from excess of Mo in the diet of rats. Higgins et al. (1956) showed that the effects of $\mathrm{W}$ or Mo on the depletion and repletion of XO are competitive, since the deleterious effects on chicks and the depletion effects on rats of a diet with a ratio of $\mathrm{W}: \mathrm{Mo}=$ rooo could be prevented by addition of further Mo to restore the ratio to normal limits. Strittmatter $(1965)$ found a competition between tungstate and molybdate in the ontogenesis of XD in chick embryos, accompanied by insignificant effects on lactate dehydrogenase or on TNAD (thionicotinamide adenine dinucleotide)-NADH (reduced nicotinamide adenine dinucleotide) transferase.

Our observation that no enhancement of the action of XO on xanthine in cow's or in goat's milk occurred when either molybdate or tungstate was added in vitro is in apparent conflict with that of Pham-Huu-Chanh (1964), who found that either molybdate or tungstate added in vitro increased the power of cow's milk to oxidize formaldehyde in the presence of methylene blue. Molybdate at $50 \mathrm{mM} / \mathrm{roo} \mathrm{ml}$ caused its maximal activation of $50 \%$. Tungstate at the same concentration, caused an activation of $79 \%$.

Caution is required in the interpretation of Pham-Huu-Chanh's results because he used formaldehyde as substrate. Milk XO can act on either formaldehyde or purine, but neither Kiermeier \& Capellari (1958), using purine, nor Hart et al. (1967), also using purine, found any change in XO activity when Mo in milk was increased by oral dosage with molybdate. The former workers, like Pham-Huu-Chanh, used methylene blue whilst the latter measured oxygen consumption. 
A hypothesis which would be consistent with all the effects of tungstate, whether in vivo or in vitro would be that tungstate can preferentially occupy enzyme sites which are normally occupied by molybdate. The effects of tungstate on the production of $\mathrm{XD}$ in bacteria and its effects on XO in the rat are not accompanied by obvious deleterious effects, but Higgins et al. (1956) argued that because chickens are uricotelic they should not be able to survive depletion of XD from the liver. However, their chickens were little troubled by the sort of Mo-poor diet which caused very low titres of XO in the rats; but, when Higgins et al. (1956) used tungstate in the diet, their chickens died with accumulations of xanthine and hypoxanthine in liver and kidney. It is perhaps important to note, in connexion with these experiments, that the XD enzyme of chicken liver consists of $\mathrm{Mo}, \mathrm{Fe}$ and flavine adenine dinucleotide combined with protein. Chemically, therefore, it is analogous to XO of milk. However, unlike the XO of milk, the chicken enzyme, when using oxygen, oxidizes hypoxanthine or xanthine to uric acid only at a very slow rate (De Angelis \& Totter, 1964). For this reason the chicken liver enzyme has for many years been called xanthine dehydrogenase in the world's biochemical literature and the name xanthine oxidase has been used for the enzyme found in milk. Both enzymes readily change xanthine or hypoxanthine to uric acid anaerobically in the presence of methylene blue or TTC so that the name xanthine dehydrogenase is often applied to both enzymes.

In our own experiments, the ruminant seems to resemble the rat rather than the chicken for no untoward symptoms resulted from the ingestion of tungstate by them. However, we gave $56 \mathrm{mg} \mathrm{W} / \mathrm{kg}$ body-weight to goats and $25 \mathrm{mg} \mathrm{W} / \mathrm{kg}$ body-weight to cows in isolated doses. By contrast, Higgins et al. (1956), whose experiments were designed for the study of toxic effects of tungstate, mixed into their animals' diets $94 \mathrm{mg} \mathrm{W} / \mathrm{kg}$ body-weight daily. Kinard \& van der Erve (194I) had to use about I $\mathrm{g}$ $\mathrm{W} / \mathrm{kg}$ before toxic symptoms appeared in rats.

\section{The form of xanthine oxidase in milk}

The widespread belief that XO and perhaps phosphatase are essential constituents of the so-called 'fat globule membrane', discussed by Webb \& Johnson (1965), still requires proof since so many species of animals give milk which contains scarcely measurable amounts of xanthine oxidase (Modi, Owen \& Proudfoot, 1959). The smaller the fat particle, the greater is the surface area per $\mathrm{g}$ fat. Goat's milk has much smaller fat particles than cow's milk, so that more XO would be expected in it, whereas experiments reveal considerably less. Sow's milk does not cream (Whittlestone, 1953) and does not contain xanthine oxidase (Modi, Owen \& Proudfoot, 1959). Exactly the same argument between cow's and goat's milk applies to phosphatase, for cow's milk has much more than goat's milk. It is difficult to fit the foregoing observations to a theory of the fat-globule membrane which requires both these enzymes as essential constituents. Thyroxine (Chanda \& Owen, 1952) increases the fat in milk while markedly diminishing its titre of phosphatase. Thyroxine also (Modi, Owen \& Darroch, 1959) has no effect on the amount of protein-bound riboflavine in cow's milk. Most of this protein-bound riboflavine should according to Hart et al. (1967) be XO. These facts also are inconsistent with the hypothesis that the fat-globule membrane is an entity of 
constant composition and therefore favour the alternative theory of Morton (I950) that $\mathrm{XO}$ and phosphatase are held to the fat globules in the milk as particles which he called 'microsomes'. Some four-fifths of milk phosphatase and similar fractions of $\mathrm{XO}$ and Mo (Archibald, 195I) rise with the cream when milk is left to stand, but this would happen on either the 'membrane' or the 'microsome' theory.

\section{REFERENCES}

Affonso, O. R. \& Mitidieri, E. (1965). Anais Acad. bras. Cienc. 37, 289.

Archibald, J. G. (1951). F. Dairy Sci. 34, 1026.

Avis, P. G., Bergel, F., Bray, R. C. \& Shooter, K. V. (1956). Symposium on Inorganic Nitrogen Metabolism, p. 552. Baltimore: John Hopkins Press.

Bauer, D. J. \& Bradley, P. L. (1956). Br. F. exp. Path. 37, 447.

Bradley, P. L. \& Gunther, M. (1960). Biochem. F. 74, I5 P.

Bray, R. C., Chisholm, A. J., Hart, L. I., Meriwether, L. S. \& Watts, D. C. (1966). Flavins and Flavoproteins, p. I 7 7. [E. C. Slater, editor.] London: Elsevier Publishing Co.

Chanda, R. \& Owen, E. C. (r952). Biochem. F. 50, 100.

Crossland, A., Owen, E. C. \& Proudfoot, R. (1958). Br. Y. Nutr. 12, 312.

De Angelis, W. J. \& Totter, J. R. (1964). F. biol. Chem. 239, 1012.

De Renzo, E. C. (r954). Ann. N.Y. Acad. Sci. 57, 905.

De Renzo, E. C., Kaleita, E., Heytler, P., Oleson, J. J., Hutchings, B. L., \& Williams, J. H. (r953). F. Am. chem. Soc. 75, 753 .

Dick, A. T. (1956). Proc. int. Grassl. Congr. vis. Wellington, New Zealand, p. 368.

Fisher, R. A. \& Yates, F. (I938). Statistical Tables. Edinburgh: Oliver and Boyd.

Hart, L. I. (I964). Some aspects of riboflavin metabolism in the ruminant. PhD Thesis, University of Glasgow.

Hart, L. I., Owen, E. C. \& Proudfoot, R. (1967). Br. Y. Nutr. 21, 6r7.

Higgins, E. S., Richert, D. A. \& Westerfeld, W. W. (1956). F. Nutr. 59, 539.

Keller, E. C. Jr \& Glassman, E. (1964). Science, N.Y. 143, 40.

Kiermeier, E. \& Capellari, K. (1958). Biochem. $Z$. 330, 160.

Kinard, F. W. \& van der Erve, J. (I941). F. Pharmac. exp. Ther. 72, I96.

Miller, R. F., Price, N. O. \& Engel, R. W. (1956). F. Nutr. 60, 539.

Mitchell, R. L. (1948). Research I, I 59.

Modi, V. V., Owen, E. C. \& Darroch, R. A. (1959). 7. Dairy Res. 26, 277.

Modi, V. V., Owen, E. C. \& Proudfoot, R. (1959). Proc. Nutr. Soc. 18, i.

Morton, R. K. (1950). Nature, Lond. 166, 1092.

Munro, H. N. (1964). In Mammalian Protein Metabolism. Vol. I, ch. 10. [H. N. Munro and J. B. Allison, editors.] London; Academic Press Inc.

Muraoka, S., Enomoto, H., Sugiyama, M. \& Yamasaki, H. (1967). Biochem. biophys. Acta 143, 408.

Neave, F. K. (1939). F. Dairy Res. 10, 475.

Owen, E. C. (1967). In Urea as a Protein Supplement, ch. 27. [H. M. Briggs, editor.] Oxford: Pergamon Press.

Owen, E. C., Hart, L. I. \& Hytten, F. E. (1962). Proc. Nutr. Soc. 2I, xv.

Owen, E. C. \& West, D. W. (1968). F. chem. Soc. (C) p. 34.

Pham-Huu-Chanh (1964). Medna exp. rr, $3^{8 .}$

Pinsent, J. (1954). Biochem. F. 57, ro.

Richert, D. A. \& Westerfeld, W. W. (1953). F. biol. Chem. 203, 915.

Roussos, G. G. (1963). Biochim. biophys. Acta 73, $33^{8}$.

Roussos, G. G. \& Morrow, B. H. (1966). Fedn Proc. Fedn Am. Socs exp. Biol. 251, no. I, p. 796.

Strittmatter, C. F. (1965). F. biol. Chem. 240, 2557.

Webb, B. H. \& Johnson, A. H. (1965). Fundamentals of Dairy Chemistry. New York: AVI Publishing Co.

West, D. W., Owen, E. C. \& Taylor, M. M. (1967). Proc. Nutr. Soc. 26, xvii.

Whittlestone, W. G. (1953). F. Dairy Res. 20, 146.

Zittle, C. A., Dellamonica, E. S., Custer, J. H. \& Rudd, R. K. (r956). J. Dairy Sci. 39, 522. 